\title{
Climate change-associated trends in biomass dynamics are consistent across soil drainage classes in western boreal forests of Canada
}

Eric B. Searle(iD and Han Y. H. Chen ${ }^{*}$

\begin{abstract}
Background: Consistent long-term declines in net aboveground biomass change have been reported in some boreal and tropical forests. Global change-type drought (i.e., demands of increased evapotranspiration exceeding soil water reserves) has been identified as the main driver for these declines. Despite the focus on reduced water availability, most studies relegate local site soil drainage to a plot random effect. However, if the major cause of some region's recent loss in net aboveground biomass change is global change-type drought, those soils with less drainage capacity should help buffer against increased evapotranspiration, resulting in less negative effects of global change-type drought on growth, mortality and net biomass change.
\end{abstract}

Methods: Here we used a network of 1279 permanent sampling plots, measured from 1958 to 2009, from western Canada, where long-term decline of climate moisture availability has been observed, to examine how soil drainage could affect the response of forest net biomass change and its components (growth and mortality) to global change-type drought.

Results: After accounting for the effects of endogenous forest age-related processes, temporal changes in absolute rates of biomass gain from growth did not differ among drainage classes, and temporal increases in biomass loss from tree mortality were also similar across drainage classes, resulting in similar decreases in net biomass change. Relative growth was significantly higher on moderately drained sites than well drained or poorly drained sites likely due to larger temporal decreases in standing biomass relative to declines in temporal growth on moderately drained soils. Moreover, growth, mortality, and net biomass change responded to atmospheric $\mathrm{CO}_{2}$, annual temperature anomaly, and standardized precipitation evapotranspiration index similarly across all drainage classes.

Conclusions: Our results suggest that climate change serves as a top-down control on forest growth, mortality and net biomass change.

Keywords: Boreal forest, Climate change, Drainage class, Growth, Local site effects, Net biomass change, Tree mortality, Water availability

\footnotetext{
* Correspondence: hchen1@lakeheadu.ca

Faculty of Natural Resources Management, Lakehead University, 955 Oliver Road, Thunder Bay, ON P7B 5E1, Canada
} 


\section{Background}

Although positive net biomass change of the world's forests is critical to offsetting global anthropogenic $\mathrm{CO}_{2}$ emission, recent studies have demonstrated that the rate of positive aboveground biomass change has decreased with calendar year due to high biomass loss from mortality coupled with growth insufficient to offset these losses (Brienen et al. 2015; Chen and Luo 2015; Chen et al. 2016). The increased tree mortality in tropical forests has been attributed to shortened tree longevity associated with greater climate variability and feedbacks of faster growth on mortality (Brienen et al. 2015). In boreal and temperate forests, increases in tree mortality (van Mantgem et al. 2009; Michaelian et al. 2011; Luo and Chen 2013; Hember et al. 2017) and decreases in aboveground biomass accumulation (Ma et al. 2012; Chen and Luo 2015; Hogg et al. 2017) have been hypothesized to be the result of warming-induced increased demand for evapotranspiration exceeding water availability (McDowell et al. 2008).

The response of net aboveground biomass change and its mortality and growth components appear strongly spatially variable (Brienen et al. 2015; Girardin et al. 2016). The variable responses to climate change could result from spatially dependent tree species composition and local site conditions. The response of aboveground biomass accumulation and wood production to climate change has been previously shown to differ with stand species composition (Coomes et al. 2014; Chen and Luo 2015) and tree mortality increases more dramatically in late-successional species than drought-tolerant earlysuccessional species in regions with temporally decreasing water availability (van Mantgem et al. 2009; Luo and Chen 2013). If the hypothesis of local evapotranspiration exceeding local soil moisture contents is the cause for increased tree mortality and decreased net aboveground biomass change, sites with rapid soil drainage should be more sensitive to climate change as these sites have less buffering capacity than sites with reduced drainage and better water retention. Recent studies have begun to support this theory. For example, across North America, more arid sites have higher tree mortality during drought conditions than more mesic and wet sites (Hember et al. 2017). Alternatively, tree species growing in drier sites have adapted to water deficit, and may be more resistant to droughts. It remains poorly understood whether the response of net aboveground biomass change and its components to climate change differ with local site conditions such as site drainage or moisture regime. A better understanding is needed to fully appreciate the impacts of climate change on forests with heterogonous local site conditions.

The central and western boreal forest presents a unique opportunity to examine this question. Not only is it topographically diverse, but it has also been shown to be strongly affected by climate change. Studies generally demonstrate a loss in net above ground biomass change (Ma et al. 2012; Chen and Luo 2015; Chen et al. 2016) and increases in mortality either due to declining water availability (Peng et al. 2011; Hember et al. 2017). The effect of climate change on tree growth in the region is more complex, with studies demonstrating: increases in young stands but no change, or even decreases, in old stands (Chen et al. 2016); a slight increase early successional conifer forest types but a decrease in latesuccessional and mixed forest types (Chen and Luo 2015); and, strongly spatially variable trends dominated by heat and drought stress (Girardin et al. 2016).

Here, we use a network of 1279 permanent sample plots across western boreal forests of Canada to specifically test whether stands on well drained sites had greater temporal decreases in growth (here defined as biomass added through both growth of surviving stems and recruitment of new stems), and temporal increases in mortality than stands on less drained sites during the past half-century. Since aboveground biomass change and its components are strongly regulated by forest age in the boreal forest (Oliver and Larson 1990), and long-term temporal trends are forest age-dependent (Chen et al. 2016), we modelled age as a continuous function, similar to previous studies (Chen and Luo 2015; Chen et al. 2016).

\section{Methods \\ Study area}

To examine the simultaneous effects of endogenous processes and climate change, we used data from a network of Permanent Sample Plots (PSPs), established throughout Alberta and Saskatchewan. We selected plots according to four criteria (i) PSPs had a known origin date of stand replacing wildfire, and were unmanaged; (ii) PSPs had all trees marked and tagged with diameter at breast height $(\mathrm{DBH})$ and species identification accurately tracked over multiple censuses; and, (iii) PSPs had to have a minimum of three censuses; and (iv) plot size, soil drainage class, and spatial location were available. All plots were established in visually homogenous wellstocked stands greater than 1 ha in size, at least $100 \mathrm{~m}$ from any openings to minimize the impacts of edge effects (Frey 1981). The selection process resulted in 1279 plots. These plots range in latitude from $49.0^{\circ}$ to $59.7^{\circ} \mathrm{N}$ and in longitude from $119.7^{\circ}$ to $95.3^{\circ} \mathrm{W}$ (Additional file 1: Figure S1). Plots were established between 1958 and 2001, final censuses were conducted on the selected plots from 1963 to 2009, and time between censuses varied from 3 to 28 years, with a mean of 9.5 years. Plot sizes varied from $202 \mathrm{~m}^{2}$ to $2023 \mathrm{~m}^{2}$ with a mean of $976 \mathrm{~m}^{2}$. Time since stand-replacing wildfire varied from 15 years to 316 years, with a mean of 100 years. Across space and time, annual 
temperatures ranged from -5.77 to $11.67{ }^{\circ} \mathrm{C}$, and annual precipitation ranged from $187 \mathrm{~mm}$ to $882 \mathrm{~mm}$ between 1957 and 2014, determined using the BioSIM 10 software (Réginère et al. 2014). Over the course of the observations, the study region underwent several persistent droughts, and a general increase in temperature (Diffenbaugh and Field 2013). The dominant species of the region include deciduous Populus tremuloides (Michx.), Populus balsamifera (L.), and Betula papyrifera (Marshall) as well as the coniferous Pinus banksiana (Lamb.), Pinus contorta (Douglas), Picea mariana (Mill.), Abies balsamea ((L.) Mill) and Picea glauca ((Moench) Voss.). Wildfire typically occurs in the region every 15-90 years (Larsen 1997; Weir et al. 2000).

As the provinces had different criteria for measuring trees (Alberta $\geq 9.1 \mathrm{~cm} \mathrm{DBH}$, Saskatchewan $\geq 9.2 \mathrm{~cm}$ $\mathrm{DBH}$ ), a threshold of $9.2 \mathrm{~cm} \mathrm{DBH}$ was used. If a tree subject to a mortality event had a smaller DBH than its last previous alive measurement, it was assigned the previous $\mathrm{DBH}$. If a tree was missing from one census to another, it was deemed dead and assigned its previous (alive) DBH. Finally, if a tree's growth was greater than

Table 1 Growth, mortality, and net biomass change associated with drainage class, forest age, and calendar year

\begin{tabular}{lllll}
\hline Fixed effects & Sum of squares & \multicolumn{1}{l}{ df } & $F$ & $P$ \\
\hline Biomass gain from growth $\left(\mathrm{Mg} \mathrm{ha}^{-1}\right.$ year $\left.^{-1}\right)$ & & & \\
$D$ & 0.80 & $2,1466.1$ & 2.41 & 0.090 \\
$f(A)$ & 12.33 & $1,1441.8$ & 73.97 & $<0.001$ \\
$Y$ & 0.96 & $1,4019.7$ & 5.75 & 0.017 \\
$D \times f(A)$ & 0.01 & $2,1546.8$ & 0.02 & 0.976 \\
$D \times Y$ & 0.86 & $2,4029.4$ & 2.58 & 0.076 \\
$f(A) \times Y$ & 0.49 & $1,3444.6$ & 2.96 & 0.085 \\
Biomass loss from & mortality $\left(\right.$ Mg ha $^{-1}$ year $\left.^{-1}\right)$ & & \\
$D$ & 14.77 & $2,1713.4$ & 6.39 & 0.002 \\
$f(A)$ & 43.72 & $1,1615.1$ & 37.83 & $<0.001$ \\
$Y$ & 21.45 & $1,3898.2$ & 18.56 & $<0.001$ \\
$D \times f(A)$ & 20.86 & $2,1716.9$ & 9.02 & $<0.001$ \\
$D \times Y$ & 3.61 & $2,3933.1$ & 1.56 & 0.210 \\
$f(A) \times Y$ & 0.66 & $1,3588.3$ & 0.57 & 0.450 \\
Net biomass change $\left(\right.$ Mg ha $^{-1}$ year $\left.^{-1}\right)$ & & & \\
$D$ & 11.56 & $2,1804.6$ & 4.06 & 0.017 \\
$f(A)$ & 143.50 & $1,1643.9$ & 100.89 & $<0.001$ \\
$Y$ & 34.16 & $1,3854.9$ & 24.02 & $<0.001$ \\
$D \times f(A)$ & 30.33 & $2,1729.9$ & 10.66 & $<0.001$ \\
$D \times Y$ & 8.38 & $2,3901.1$ & 2.95 & 0.053 \\
$f(A) \times Y$ & 0.19 & 1,3646 & 0.13 & 0.714 \\
\hline
\end{tabular}

Forest age is logarithmically transformed $(\operatorname{In} F A)$ and calendar year is represented by Year. Linear mixed-effects model fit tests used Satterthwaite approximations of degrees of freedom
$2 \mathrm{~cm}$ a year, it was examined for data entry mistakes (e.g., an incorrect decimal).

\section{Biomass calculations}

Similar to previous studies (Chen and Luo 2015; Chen et al. 2016; Hogg et al. 2017; Searle and Chen 2017a), above-ground biomass for each individual stem was calculated for individual trees using species' specific allometric equations developed for all major boreal tree species (Lambert et al. 2005; Ung et al. 2008). The biomass of individual stems were summed across each plot to obtain stand-level estimates. The annual net aboveground biomass change $(\triangle \mathrm{AGB})$ was calculated as the total live biomass at the census minus the total live biomass at the previous census divided by the time between censuses (interval). Annual change in above-ground biomass growth $\left(\triangle \mathrm{AGB}_{\mathrm{GI}}\right)$ was calculated as the biomass gain of live trees between censuses plus biomass gain from recruited trees divided by the interval. Annual change in above-ground biomass loss due to mortality $\left(\triangle \mathrm{AGB}_{\mathrm{M}}\right)$ was calculated as the biomass lost due to mortality divided by the interval. Relative biomass growth,

Table 2 Relative growth, mortality, and net biomass change associated with drainage class, forest age, and calendar year

\begin{tabular}{lllll}
\hline Fixed effects & Sum of squares & df & $F$ & $P$ \\
\hline Biomass gain from growth $\left(\%\right.$ year $\left.^{-1}\right)$ & & & \\
$D$ & 1.30 & $2,1226.5$ & 4.03 & 0.018 \\
$f(A)$ & 27.54 & $1,1404.2$ & 170.78 & $<0.001$ \\
$Y$ & 4.16 & $1,4200.9$ & 25.78 & $<0.001$ \\
$D \times f(A)$ & 3.57 & 2,1558 & 11.07 & $<0.001$ \\
$D \times Y$ & 9.45 & $2,4183.5$ & 29.31 & $<0.001$ \\
$f(A) \times Y$ & 24.79 & $1,3871.3$ & 153.68 & $<0.001$ \\
Biomass loss from mortality $\left(\%\right.$ year $\left.^{-1}\right)$ & & & \\
$D$ & 3.69 & $2,1717.4$ & 3.35 & 0.035 \\
$f(A)$ & 7.48 & $1,1658.6$ & 13.57 & $<0.001$ \\
$Y$ & 7.21 & $1,3898.4$ & 13.08 & $<0.001$ \\
$D \times f(A)$ & 5.61 & $2,1814.4$ & 5.09 & 0.006 \\
$D \times Y$ & 0.61 & $2,3899.3$ & 0.55 & 0.578 \\
$f(A) \times Y$ & 2.65 & $1,3729.5$ & 4.80 & 0.029 \\
Net biomass change $\left(\%\right.$ year $\left.^{-1}\right)$ & & & \\
$D$ & 17.35 & $2,1393.2$ & 11.02 & $<0.001$ \\
$f(A)$ & 136.93 & $1,1341.1$ & 173.96 & $<0.001$ \\
$Y$ & 27.00 & 1,3794 & 34.30 & $<0.001$ \\
$D \times f(A)$ & 16.51 & $2,1484.8$ & 10.49 & $<0.001$ \\
$D \times Y$ & 17.84 & $2,3794.3$ & 11.33 & $<0.001$ \\
$f(A) \times Y$ & 7.00 & $1,3571.9$ & 8.89 & 0.003 \\
\hline
\end{tabular}

Forest age is the inverse of logarithmically transformed age $\left(\operatorname{InFA} A^{-1}\right)$ and calendar year is represented by Year. Linear mixed-effects model fit tests used Satterthwaite approximations of degrees of freedom 
mortality, and net biomass change were calculated as the absolute value divided by the mean standing biomass between the two focal census periods.

\section{Explanatory variables}

We used calendar year to represent temporal changes in climatic conditions as a whole, following previous studies (Brienen et al. 2015; Chen et al. 2016; Searle and Chen 2017a), corresponding to each observation of $\triangle A G B$, relative $\triangle \mathrm{AGB}$ and their related components. This encompasses not only the systematic increases in atmospheric $\mathrm{CO}_{2}$ concentration and temperature and a decrease in climate moisture index, but also the changes in other climatic and non-climatic drivers.

Soil drainage class of each plot was categorized into three major groupings: well-drained, moderately-drained, and poorly-drained. These values correspond to a soil drainage class value of $1-3,4 \& 5,6 \& 7$, respectively. These values were inferred from the pore pattern and depth of mineral soils, the topographic position of the site, and physical characteristics of the soil profile including humus depth, location of the water table, permeability, and water storage capacity (Frey 1981; Alberta Sustainable Resource Development 2005). Of the 1279 plots selected for this analysis, 161 were well drained, 1071 were moderately drained, and 47 were poorly drained. Of the 47 poorly drained sites included in our analysis only two were identified as fully saturated for the entirety of the growing season.

Similar to our previous studies (Luo and Chen 2013; Chen et al. 2016; Searle and Chen 2017a), we used forest age to account for endogenous stand processes, interpretable as time since fire as all selected stands originated from wildfire. Forest age for each PSP was determined according to a known fire or by coring at least three dominant/co-dominant trees of each tree species inside or outside the plot at the time of plot establishment. When coring was used, the average ring counts of the tree samples for the species with the oldest age was used to determine time since fire by species-specific relationships
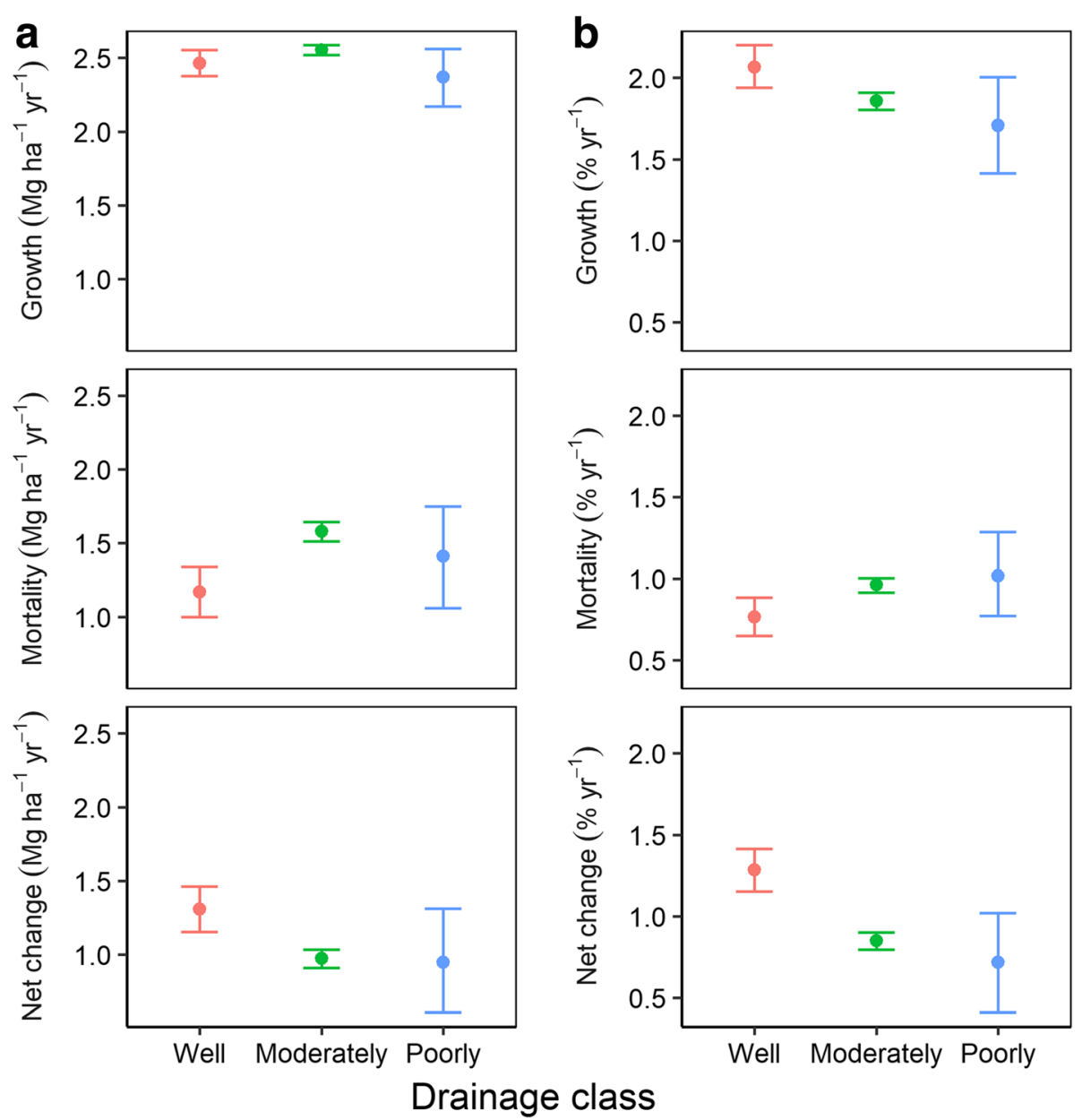

Fig. 1 Mean absolute and relative growth, mortality, and net biomass change of western boreal forests of Canada during 1958-2009 in relation to drainage class. a Absolute rates and (b) relative rates. Values are bootstrapped means and their $95 \%$ confidence intervals 
between forest age and time since fire developed for boreal forests (Gutsell and Johnson 2002; Huang et al. 2009). With all data pooled, there was a weak positive correlation between forest age and calendar year $\left(r=0.12, \mathrm{R}^{2}=0.014\right)$. There are three possible approaches to disentangle their joint variation. The first is to model their effects simultaneously. The second is to use residual and sequential regressions by assigning the priority to forest age and then modelling the effects of year and its interaction with forest age on the residuals (Graham 2003; Cohen et al. 2013). The third is to reverse the priority in the second approach. However, as we have no logical or theoretical basis for considering any variable to be prior in terms of a hypothetical causal structure of the data (Cohen et al. 2013), and assigning priority to forest age would marginalise the year effect, and vice versa (Brown et al. 2011; Chen et al. 2016), we reported the results from simultaneously modelling effects of forest age and year.
To understand the influence of individual climate change drivers on $\triangle \mathrm{AGB}$ and its related components, we derived $\mathrm{CO}_{2}$ measurements from the Mauna Loa Earth System Research Laboratory in Hawaii (http://www.esrl. noaa.gov/gmd/ccgg/trends/co2_data_mlo.html) and from the Law Dome DE08 and DE08-2 ice cores (http:// cdiac.ornl.gov/ftp/trends/co2/lawdome.smoothed.yr20). We also calculated the annual temperature anomaly (ATA) for each census, defined as the annual mean annual temperature of a plot minus the average annual temperature for the plot throughout the study period. To assess temporal changes in climate moisture availability, we calculated the standardized precipitation evapotranspiration index (SPEI). The index is standardized to a location and has been shown to be an excellent indicator of water availability that is directly comparable across large spatial and temporal gradients (Vicente-Serrano et al. 2010). We used monthly precipitation and evapotranspiration derived from BioSIM to calculate a yearly SPEI, using the SPEI, version
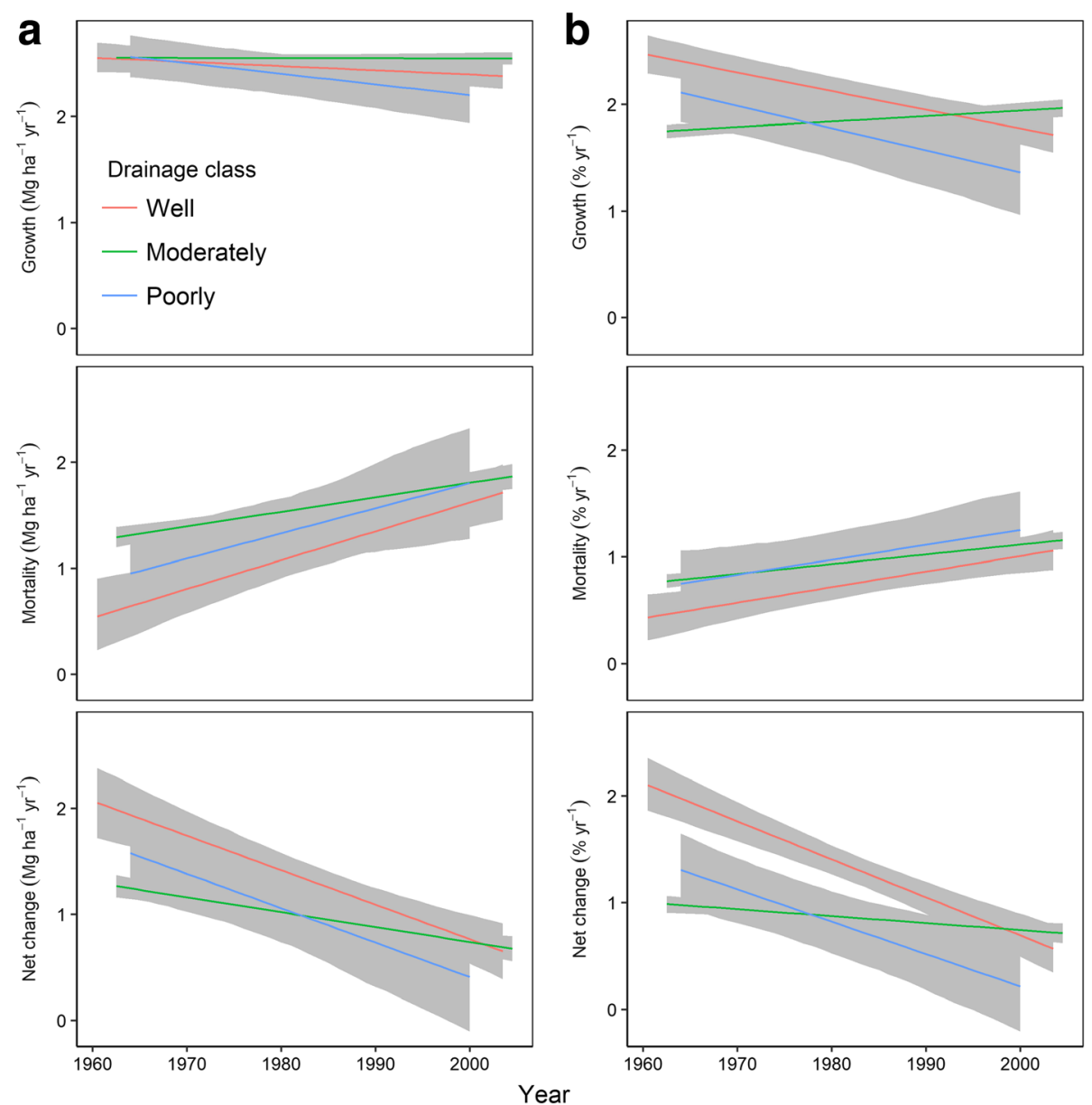

Fig. 2 The response of growth, mortality, and net biomass change of western boreal forests of Canada to calendar year in relation to drainage class. a Absolute rates and (b) relative rates. The effects of calendar year were determined by simultaneously accounting for the effects forest age. Lines are bootstrapped means with 95\% confidence intervals in shade. Plots with background points to demonstrate fits are presented in Additional file 1: Figure S3 
1.6, package in R (Vicente-Serrano et al. 2010). We then calculated the average value of each driver over the census interval. Over the study period, there was a general increase in temperature, decrease in SPEI, and increase in atmospheric $\mathrm{CO}_{2}$ (Additional file 1: Figure S2).

\section{Data analysis}

To address how drainage classes might affect climate change associated trends in stand level $\triangle A G B$, relative $\triangle \mathrm{AGB}$ and their related components, we tested the effects of forest age, calendar year (climate change as a whole), soil drainage and all two-way interactions using the following linear mixed effects model:

$$
\begin{aligned}
\Delta \mathrm{AGB}_{\mathrm{ij}}= & \beta_{0}+\beta_{1} \cdot D_{j}+\beta_{2} \cdot Y_{i j}+\beta_{3} \cdot f\left(A_{i j}\right)+\beta_{4} \cdot D_{j} \times Y_{i j}+ \\
& \beta_{5} \cdot D_{j} \times f\left(A_{i j}\right)+\beta_{6} \cdot Y_{i j} \times f\left(A_{i j}\right)+\pi_{j}
\end{aligned}
$$

where $D$ is the soil drainage class of the plot, $Y$ is the mid-calendar year, and $f(A)$ is natural logarithm of forest age for absolute $\triangle \mathrm{AGB}$ models and is the inverse of the natural logarithm of forest age for relative $\triangle A G B . \pi$ is the random plot error, which accounts for plot specific effects other than drainage class, such as plot size, nutrient regime, and species composition. Similar to previous studies using plot networks consisting of plots of varying sizes and census lengths (Brienen et al. 2015; Chen et al. 2016), we weighted each observation by the square root of the plot size in hectares times the total plot census length. All variables were centered prior to analysis to speed convergence and aid in interpretation. In order to derive overall temporal trends, we fit a similar model to eq. 1 but omitted the drainage class year interaction $\left(\beta_{6}\right)$.

To better understand the influences of temporal changes in climate on $\triangle \mathrm{AGB}$, relative $\triangle \mathrm{AGB}$ and their components, we substituted $Y$ in Eq. 1 with atmospheric carbon dioxide concentration, ATA, and SPEI and modeled each driver
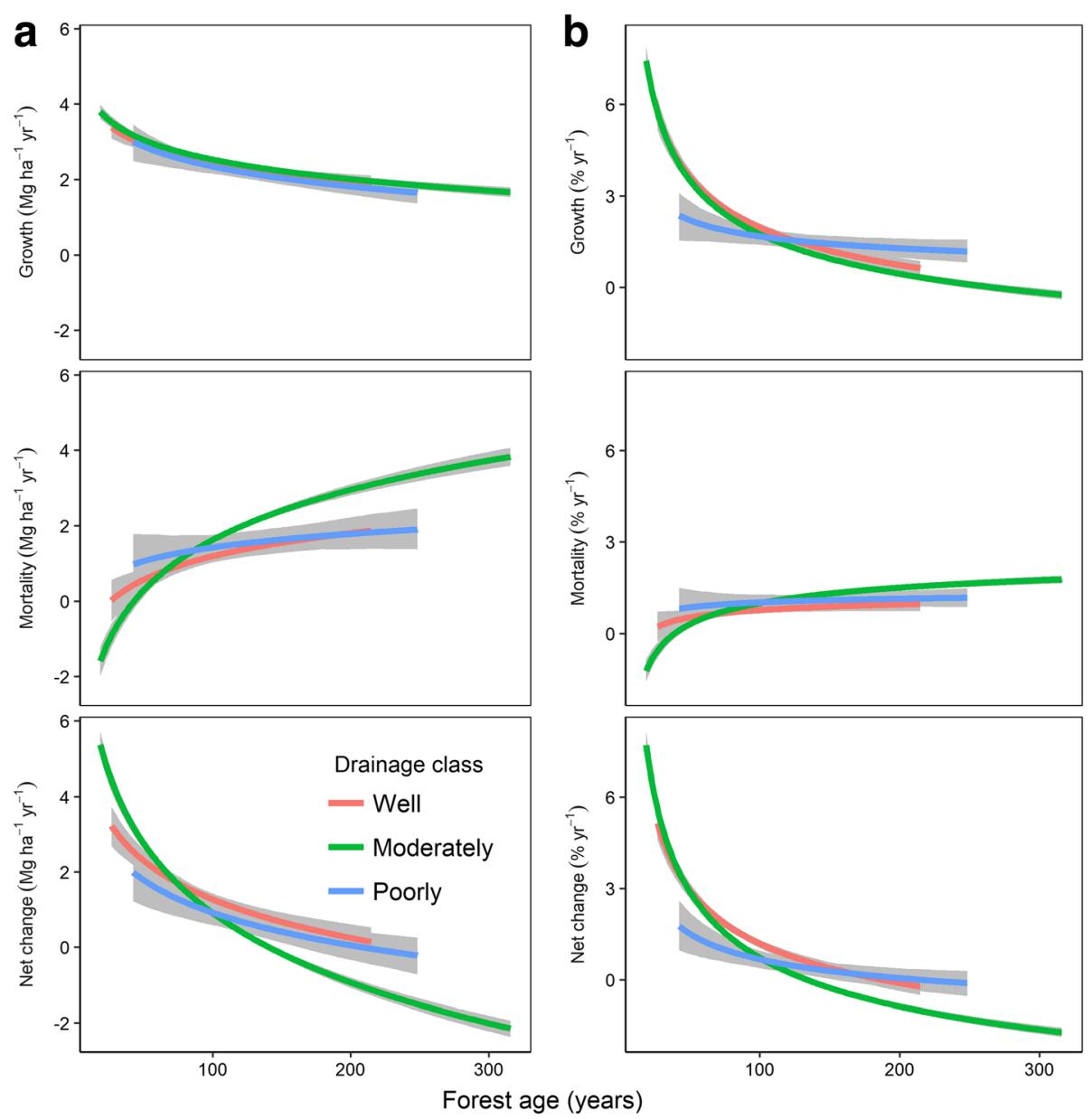

Fig. 3 The response of growth, mortality, and net biomass change of western boreal forests of Canada to forest age in relation to drainage class. a Absolute rates and $(\mathbf{b})$ relative rates. The effects of forest age were determined by simultaneously accounting for the effects of calendar year. Lines are bootstrapped means with 95\% confidence intervals in shade. Plots with background points to demonstrate fits are presented in Additional file 1: Figure S4 
independently. Our analysis is parametric and assumes normality of residuals; however, model residuals for $\triangle \mathrm{AGB}$ were left-skewed, model residuals for $\triangle \mathrm{AGB}_{\mathrm{GI}}$ and $\triangle \mathrm{AGB}_{\mathrm{M}}$ were right-skewed and residuals of relative $\triangle \mathrm{AGB}$ and its components were leptokuric. To account for this, all models were bootstrapped 1000 times to generate 95\% confidence intervals. Graphical representation of the trends was performed according to methods developed by Chen et al. (2016). Analysis was conducted in R 3.4.0 ( $\mathrm{R}$ Core Development Team 2017), using the lme4 package (Bates et al. 2015).

\section{Results}

Absolute and relative mortality and net biomass change differed significantly among drainage classes while absolute growth differed marginally between drainage classes (Tables 1 and 2). On average over the sampling period, growth was $2.46 \pm 0.09$ (mean \pm bootstrapped 95\% confident intervals), $2.55 \pm 0.03$, and $2.37 \pm 0.19 \mathrm{Mg}$ $\mathrm{ha}^{-1}$ year $^{-1}$ on well, moderately, and poorly drained soils, respectively. Mortality was $1.17 \pm 0.16,1.58 \pm 0.07$, and $1.43 \pm 0.35 \mathrm{Mg} \mathrm{ha}^{-1}$ year $^{-1}$ on well, moderately, and poorly drained soils, respectively. Net biomass change was
$1.30 \pm 0.15,0.97 \pm 0.06$, and $0.96 \pm 0.35 \mathrm{Mg} \mathrm{ha}^{-1}$ year $^{-1}$ on well, moderately, and poorly drained soils, respectively (Fig. 1a). Relative growth was $2.06 \pm 0.13,2.06 \pm 0.05$, and $1.70 \pm 0.30 \%$ year $^{-1}$; relative mortality was $0.77 \pm 0.11$, $0.96 \pm 0.05$ and $1.02 \pm 0.24 \%$ year $^{-1}$; and relative net biomass change was $1.29 \pm 0.13,0.85 \pm 0.05$ and $0.72 \pm 0.31 \%$ year $^{-1}$ on well, moderately, and poorly drained soils, respectively (Fig. 1b).

After accounting for the effects of forest ageing, both absolute and relative rates of growth, mortality, and net biomass change changed significantly with calendar year (Tables 1 and 2). Across all drainage classes, absolute growth declined at $-0.001 \pm 0.002 \mathrm{Mg} \mathrm{ha}^{-1}$ year $^{-1}$ with calendar year, while absolute mortality increased at $0.015 \pm 0.004 \mathrm{Mg} \mathrm{ha}^{-1}$ year $^{-2}$, resulting in a decline of absolute net biomass change of $0.016 \pm 0.004 \mathrm{Mg}$ $\mathrm{ha}^{-1}$ year $^{-2}$ (Table 1; Fig. 2a). The temporal trends in growth, mortality, and net biomass change did not differ significantly among drainage classes, as indicated by insignificant interactions of calendar year and drainage class (Table 1; Fig. 1b).

The responses of relative growth rate and net biomass change to calendar year differed significantly among

Table 3 The responses ( $P$ values) of absolute and relative growth, mortality, and net biomass change to atmospheric $\mathrm{CO}_{2}\left(\mathrm{CO}_{2}\right)$, mean annual temperature anomaly (ATA) and standardized precipitation evapotranspiration index (SPEI), drainage class, and forest age

\begin{tabular}{|c|c|c|c|c|c|c|}
\hline Fixed effects & $\begin{array}{l}\text { Biomass gain } \\
\text { from growth } \\
\left(\mathrm{Mg} \mathrm{ha}^{-1} \text { year }^{-1}\right)\end{array}$ & $\begin{array}{l}\text { Biomass loss } \\
\text { from mortality } \\
\left(\mathrm{Mg} \mathrm{ha}^{-1} \text { year }^{-1}\right)\end{array}$ & $\begin{array}{l}\text { Net biomass change } \\
\left(\mathrm{Mg} \mathrm{ha}^{-1} \text { year }^{-1}\right)\end{array}$ & $\begin{array}{l}\text { Biomass gain from } \\
\text { growth }\left(\% \text { year }{ }^{-1}\right)\end{array}$ & $\begin{array}{l}\text { Biomass loss from } \\
\text { mortality }\left(\% \text { year }^{-1}\right)\end{array}$ & $\begin{array}{l}\text { Net biomass } \\
\text { change }\left(\% \text { year }^{-1}\right)\end{array}$ \\
\hline \multicolumn{7}{|c|}{ Atmospheric carbon dioxide concentration } \\
\hline$D$ & 0.094 & 0.002 & 0.017 & 0.017 & 0.035 & $<0.001$ \\
\hline$f(A)$ & $<0.001$ & $<0.001$ & $<0.001$ & $<0.001$ & $<0.001$ & $<0.001$ \\
\hline $\mathrm{CO}_{2}$ & 0.008 & $<0.001$ & $<0.001$ & $<0.001$ & $<0.001$ & $<0.001$ \\
\hline$D \times f(A)$ & 0.976 & $<0.001$ & $<0.001$ & $<0.001$ & 0.005 & $<0.001$ \\
\hline $\mathrm{D} \times \mathrm{CO}_{2}$ & 0.066 & 0.158 & 0.032 & $<0.001$ & 0.490 & $<0.001$ \\
\hline$f(A) \times \mathrm{CO}_{2}$ & 0.046 & 0.683 & 0.974 & $<0.001$ & 0.055 & 0.002 \\
\hline \multicolumn{7}{|c|}{ Annual temperature anomaly } \\
\hline$D$ & 0.122 & 0.003 & 0.030 & 0.073 & 0.051 & $<0.001$ \\
\hline$f(A)$ & $<0.001$ & $<0.001$ & $<0.001$ & $<0.001$ & $<0.001$ & $<0.001$ \\
\hline ATA & 0.373 & 0.002 & 0.002 & 0.006 & 0.009 & $<0.001$ \\
\hline$D \times f(A)$ & 0.889 & $<0.001$ & $<0.001$ & $<0.001$ & 0.015 & $<0.001$ \\
\hline$D \times A T A$ & 0.336 & 0.882 & 0.877 & $<0.001$ & 0.747 & 0.100 \\
\hline$f(A) \times A T A$ & 0.086 & 0.036 & 0.207 & $<0.001$ & 0.001 & 0.867 \\
\hline \multicolumn{7}{|c|}{ Standardized precipitation-evapotranspiration index } \\
\hline$D$ & 0.138 & 0.004 & 0.027 & 0.044 & 0.046 & $<0.001$ \\
\hline$f(A)$ & $<0.001$ & $<0.001$ & $<0.001$ & $<0.001$ & $<0.001$ & $<0.001$ \\
\hline SPEI & 0.114 & 0.021 & 0.006 & 0.159 & 0.005 & 0.004 \\
\hline$D \times f(A)$ & 0.517 & $<0.001$ & $<0.001$ & 0.001 & 0.002 & $<0.001$ \\
\hline$D \times S P E I$ & 0.179 & 0.650 & 0.618 & 0.041 & 0.582 & 0.065 \\
\hline$f(A) \times S P E I$ & 0.337 & 0.010 & 0.026 & $<0.001$ & 0.048 & 0.020 \\
\hline
\end{tabular}


drainage classes, while calendar year trends related to mortality did not differ significantly (Table 2). Responses of relative growth to calendar year were $-0.017 \pm 0.006$, $0.005 \pm 0.002$ and $-0.021 \pm 0.008 \%$ year $^{-2}$; and relative net biomass change was $-0.036 \pm 0.009,-0.006 \pm 0.003$ and $-0.030 \pm 0.014 \%$ year $^{-2}$ on well, moderately, and poorly drained soils, respectively (Fig. 2b).

Both absolute and relative growth, mortality, and net biomass change responded significantly to forest ageing (Tables 1 and 2). Growth declined with forest ageing on all soil types, while mortality increased more significantly on moderately drained soils than on poorly or well drained soils, leading to a significantly larger decline in net biomass change on moderately drained soils than on poorly or well drained soils with forest ageing (Table 1; Fig. 3a). Relative growth rates and net biomass change had an initial sharp decline with forest ageing, with the largest declines on well drained followed by moderately drained soils (Table 2 \& Fig. 3b). Relative mortality had a sharp initial increase with forest ageing, highest on moderately drained soils, followed by a relatively consistent increase (Table 2 \& Fig. 3b).

As atmospheric $\mathrm{CO}_{2}$ had a tight correlation to calendar year $\left(r^{2}=0.97\right.$, Additional file 1: Figure S2), trends in both absolute and relative growth, mortality, and net biomass change responses to atmospheric $\mathrm{CO}_{2}$ largely followed those of calendar year although poorly drained sites had significantly lower growth than moderately drained or well drained sites (Table 3, Figs. 4a and 5a). Absolute growth did not respond to increasing ATA, but absolute mortality increased, resulting in a similar decrease in absolute net biomass change across all soil drainage classes (Table 3, Fig. 4b). Trends in absolute mortality related to temperature were also age-dependent, with older ages having increased rates of mortality with increasing temperatures (Table 3). The response of relative growth to increasing temperature was comparable to temporal trends, with increases on moderately drained sites and decreases on well drained and poorly drained sites (Table 3, Fig. 5b). With decreasing SPEI, absolute growth decreased,

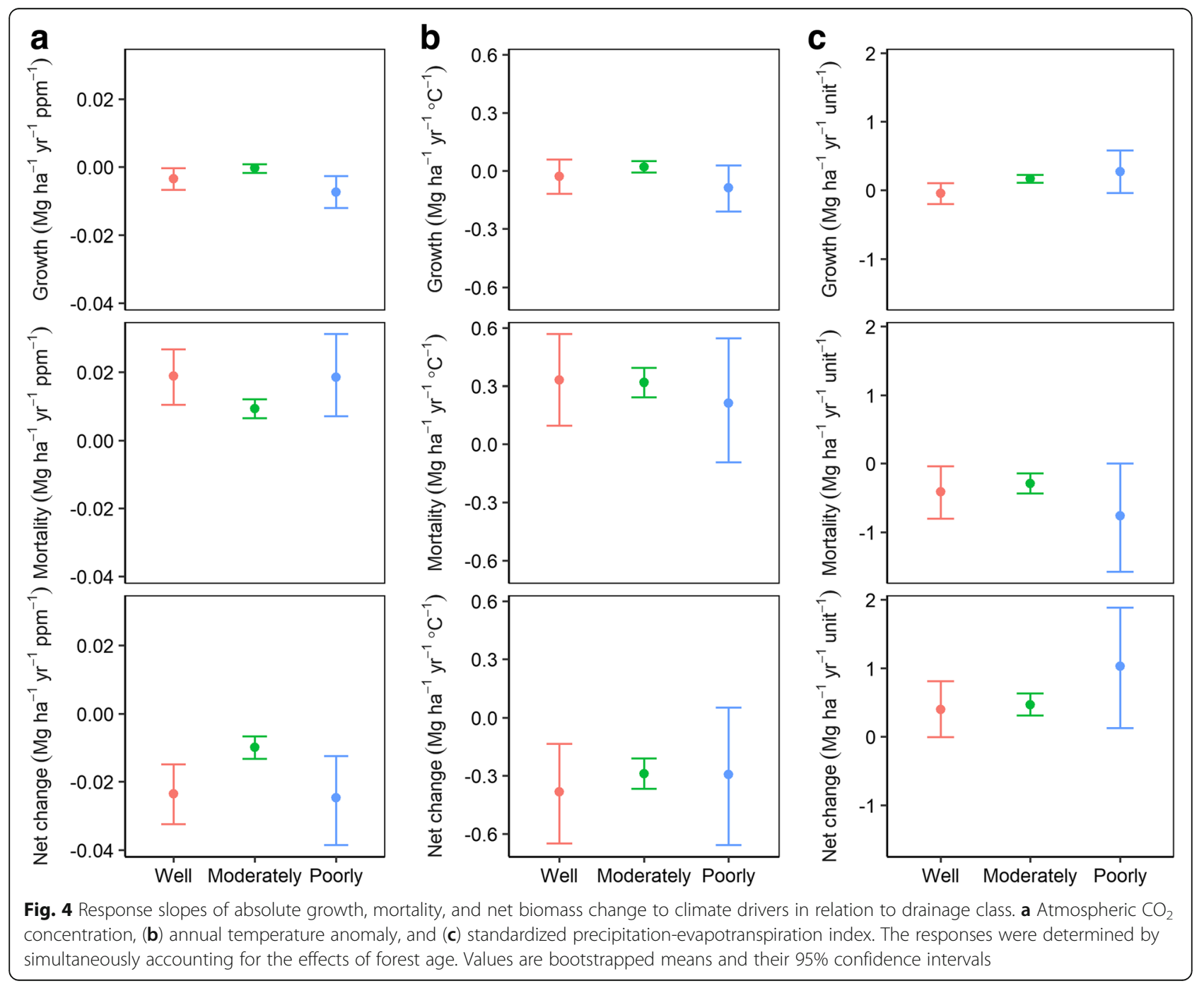




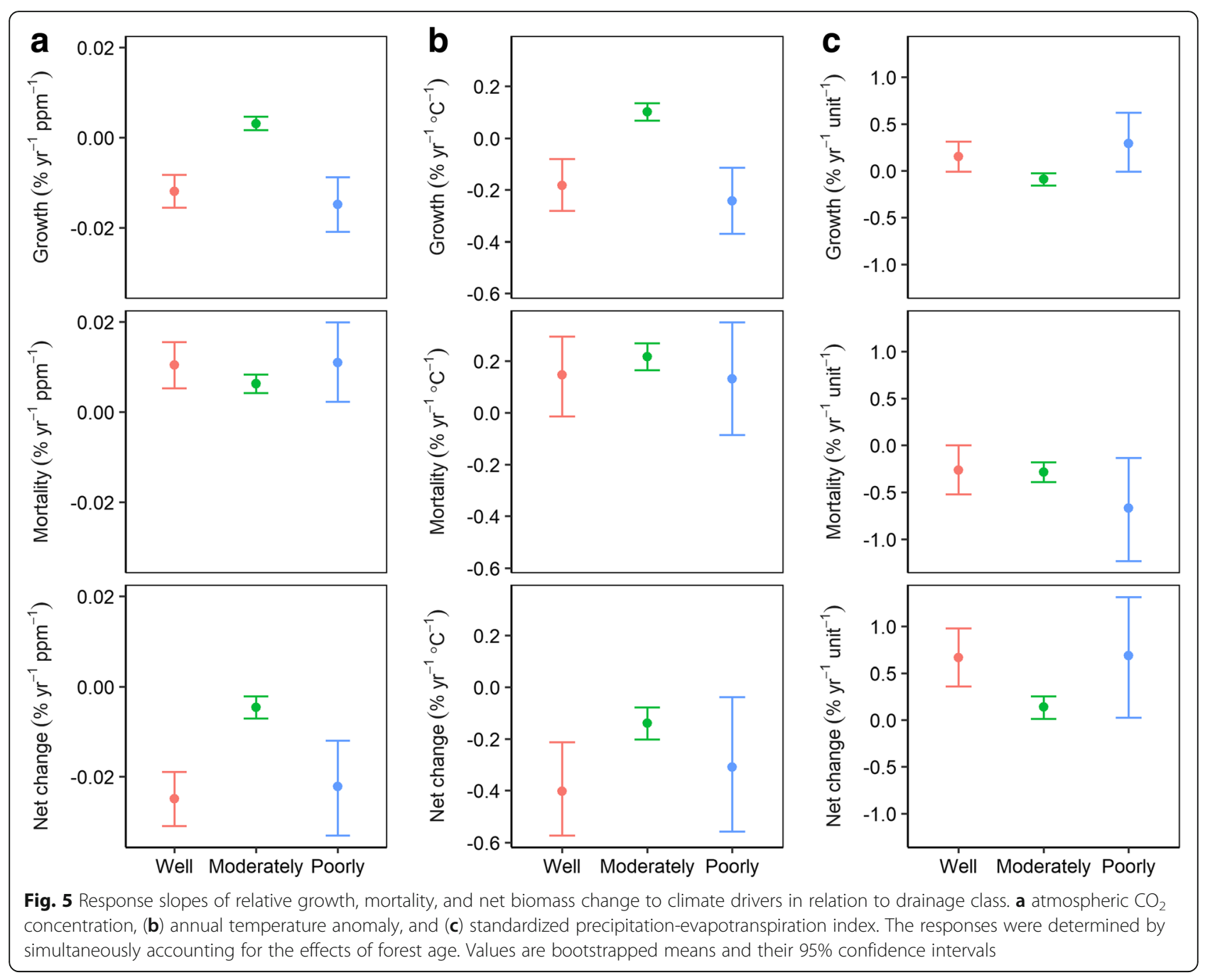

while loss from mortality increased, leading to a decline in absolute net biomass change with no significant difference among drainage classes (Table 3, Fig. 4). Trends in absolute growth and mortality responses to SPEI were also age dependent, with growth being less affected in older stands than in younger stands, but a large increase in mortality in older stands (Table 3). With decreasing SPEI, relative growth differed significantly between drainage classes while relative mortality increased, and relative net biomass change decreased with no significant differences among drainage classes (Table 3, Fig. 5c).

\section{Discussion}

We found that temporal trends in both absolute and relative growth, mortality, and net biomass change associated with climate change were largely consistent across three drainage classes. Although we predicted that well drained sites would have more negative responses to climate change (i.e., decreased growth, increased biomass loss from mortality) than moderately or poorly drained sites, there are three major reasons we may not have observed this trend. First, it is possible that well drained sites foster a species community that is already resistant to lower water availability while sites with higher water retention benefit from having a soil water buffer. Previous studies in the boreal forest have emphasized the role of local site suitability in determining species compositions (Chen and Taylor 2012) and have demonstrated that these forests are moving towards more drought resistant early-successional conifers in response to climate change (Searle and Chen 2017a). These abiotic sorting mechanisms, and background compositional shifts, could be enhancing stand resistance to lowered water availability on well drained sites. Second, it is possible that communities, irrespective of composition, have adapted to local water availability conditions. Thus, responses of growth, mortality and net biomass change to temporal declines in water availability may be less dependent on local site conditions (to which communities 
are adapted) and more dependent on the magnitude of temporal decline. Third, we only examined long-term temporal and water availability trends. It is possible that well drained sites are more susceptible to singular drought events than less drained sites although examination of this would require more evenly sampled plots or dendrochronological techniques (e.g., Hogg et al. 2017). However, if this were the case, we might still expect to find a long-term difference as trees that experience droughts often have long-term growth reductions (Anderegg et al. 2015).

While absolute and relative measures of biomass dynamics were generally in agreement, relative growth increased over our study period on moderately drained sites but decreased significantly on well and poorly drained sites, whereas absolute growth consistently declined across all drainage classes. The discrepancy in direction between relative and absolute growth on moderately drained sites is likely an artifact of the calculation of relative growth rates. We calculated relative growth rates as the absolute growth rate divided by the mean standing biomass - if standing biomass declined more than absolute growth rates due to temporally increased absolute biomass loss from mortality, then relative growth rates would increase. The discrepancy in temporal trends in relative growth rates drove the differences in net biomass change; although net change declined across all drainage classes since relative mortality declined more than relative growth increased on moderately drained sites. It is also important to note that our study focusses on large trees (i.e., trees $\geq 9.2 \mathrm{~cm}$ in diameter at breast height). While this may bias our estimates of age effects, estimates of temporal trends have been shown to be consistent across diameter thresholds within boreal forests (Searle and Chen 2017b).

Our sensitivity analysis using climactic drivers further emphasizes that forests growing on different drainage classes are being affected similarly in the western boreal forest. There was no evidence that increasing temperatures or decreasing water availability adversely affected well drained sites more than moderately or poorly drained sites. However, we did find an overall temporal decline in net biomass change driven by higher loss from mortality over the past half-century in response, consistent with other studies in the region (Ma et al. 2012; Chen and Luo 2015; Chen et al. 2016) highlighting the negative impact of reduced water availability.

It is interesting that previously reported increased tree mortality rates to drought on more arid sites (Hember et al. 2017) were not reflected in our stand-level analysis. However, it is important to note that we used explicit measurements of drainage class as our measure of site water availability rather than the approach of
Hember et al. (2017) who used average long-term climactic water availability as measured by aridity index. A recent tree ring analysis from across the boreal forest of Canada found a positive effect of a long-term soil moisture index (calculated using precipitation and evapotranspiration rates) and growth (Girardin et al. 2016). Together, these results suggest that long-term regional climates have pronounced effects on forest growth, mortality and net biomass change, irrespective of local site condition.

\section{Conclusion}

We found no evidence that drainage class influences estimates of temporal trends in growth, mortality, and net biomass change. Sensitivity analysis further confirmed that drainage class does not alter forest response to increases in atmospheric carbon dioxide and temperature, and decreases in water availability. Our results suggest that climate change acts as top-down control on forest growth, mortality and net biomass change, irrespective of local site condition.

\section{Additional file}

\begin{abstract}
Additional file 1: Figure S1. Map of sites and associated drainage classes across Alberta and Saskatchewan. Figure S2. Change in climactic drivers across all plots during the study period. Figure S3. Trends in a) absolute and b) relative growth, mortality, and net biomass change associated with calendar year after accounting for the effects of drainage class and forest age. Figure S4. Trends in a) absolute and b) relative growth, mortality, and net biomass change associated with forest age after accounting for the effects of drainage class and calendar year. (DOCX $618 \mathrm{~kb}$ )
\end{abstract}

\section{Acknowledgements}

We thank Ken Stadt and the Alberta Ministry of Agriculture and Forestry and Phil Loseth and the Saskatchewan Ministry of the Environment for collecting and archiving the related datasets; Gordon Kayahara, Chander Shahi, and Brian McLaren for their helpful comments for improving this article.

\section{Funding}

This study was supported by the Natural Sciences and Engineering Research Council of Canada (RGPIN-2014-04181).

Availability of data and materials

All data is available upon request to the Alberta Ministry of Agriculture and Forestry and the Saskatchewan Ministry of the Environment. All data was collected following provincial legislation.

\section{Authors' contributions}

EBS and HYHC designed the study; EBS compiled and analysed the data; EBS and $\mathrm{HYHC}$ wrote the manuscript. Both authors read and approved the final manuscript.

\section{Competing interests}

The authors declare that they have no competing interests.

Received: 17 July 2017 Accepted: 15 September 2017

Published online: 17 October 2017

\section{References}

Alberta Sustainable Resource Development (2005) Monitor plot survey manual. Public lands and forests division, Edmonton, Alberta, 
Anderegg WR, Schwalm C, Biondi F, Camarero JJ, Koch G, Litvak M, Ogle K, Shaw JD, Shevliakova E, Williams AP, Wolf A, Ziaco E, Pacala S (2015) FOREST ECOLOGY. Pervasive drought legacies in forest ecosystems and their implications for carbon cycle models. Science 349(6247):528-532. doi:10.1126/science.aab1833

Bates D, Machler M, Bolker BM, Walker SC (2015) Fitting linear mixed-effects models using Ime4. Journal of statistical software 67(1):1-48. doi:10.18637/jss.v067.i01

Brienen RJ, Phillips OL, Feldpausch TR, Gloor E, Baker TR, Lloyd J, Lopez-Gonzalez G, Monteagudo-Mendoza A, Malhi Y, Lewis SL, Vasquez Martinez R, Alexiades M, Alvarez Davila E, Alvarez-Loayza P, Andrade A, Aragao LE, AraujoMurakami A, Arets EJ, Arroyo L, Aymard CG, Banki OS, Baraloto C, Barroso J, Bonal D, Boot RG, Camargo JL, Castilho CV, Chama V, Chao KJ, Chave J, Comiskey JA, Cornejo Valverde F, da Costa L, de Oliveira EA, Di Fiore A, Erwin TL, Fauset S, Forsthofer M, Galbraith DR, Grahame ES, Groot N, Herault B, Higuchi N, Honorio Coronado EN, Keeling H, Killeen TJ, Laurance WF, Laurance S, Licona J, Magnussen WE, Marimon BS, Marimon-Junior BH, Mendoza C, Neill DA, Nogueira EM, Nunez P, Pallqui Camacho NC, Parada A, Pardo-Molina G, Peacock J, Pena-Claros M, Pickavance GC, Pitman NC, Poorter L, Prieto A, Quesada CA, Ramirez F, Ramirez-Angulo H, Restrepo Z, Roopsind A, Rudas A, Salomao RP, Schwarz M, Silva N, Silva-Espejo JE, Silveira M, Stropp J, Talbot J, ter Steege H, Teran-Aguilar J, Terborgh J, ThomasCaesar R, Toledo M, Torello-Raventos M, Umetsu RK, van der Heijden GM, van der Hout P, Guimaraes Vieira IC, Vieira SA, Vilanova E, Vos VA, Zagt RJ (2015) Long-term decline of the Amazon carbon sink. Nature 519(7543):344-348. doi:10.1038/nature14283

Brown CJ, Schoeman DS, Sydeman WJ, Brander K, Buckley LB, Burrows M, Duarte CM, Moore PJ, Pandolfi JM, Poloczanska E, Venables W, Richardson AJ (2011) Quantitative approaches in climate change ecology. Glob Chang Biol 17(12): 3697-3713. doi:10.1111/j.1365-2486.2011.02531.x

Chen HYH, Luo Y, Reich PB, Searle EB, Biswas SR (2016) Climate changeassociated trends in net biomass change are age dependent in western boreal forests of Canada. Ecol Lett 19(9):1150-1158. doi: 10.1111/ele.12653

Chen HYH, Luo Y (2015) Net aboveground biomass declines of four major forest types with forest ageing and climate change in western Canada's boreal forests. Glob Chang Biol 21(10):3675-3684. doi:10.1111/gcb.12994

Chen HYH, Taylor AR (2012) A test of ecological succession hypotheses using 55year time-series data for 361 boreal forest stands. Glob Ecol Biogeogr 21(4): 441-454. doi:10.1111/j.1466-8238.2011.00689.x

Cohen J, Cohen P, West SG, Aiken LS (2013) Applied multiple regression/ correlation analysis for the behavioral sciences. Routledge, New York

Coomes DA, Flores O, Holdaway R, Jucker T, Lines ER, Vanderwel MC (2014) Wood production response to climate change will depend critically on forest composition and structure. Glob Chang Biol 20(12):3632-3645. doi:10.1111/gcb.12622

Diffenbaugh NS, Field CB (2013) Changes in ecologically critical terrestrial climate conditions. Science 341(6145):486-492. doi:10.1126/science.1237123

Frey GE (1981) Saskatchewan growth and yield survey field procedures manual

Girardin MP, Bouriaud O, Hogg EH, Kurz W, Zimmermann NE, Metsaranta JM, de Jong R, Frank DC, Esper J, Buntgen U, Guo XJ, Bhatti J (2016) No growth stimulation of Canada's boreal forest under half-century of combined warming and CO2 fertilization. Proc Natl Acad Sci U S A 113(52):E8406-E8414. doi:10.1073/pnas.1610156113

Gutsell SL, Johnson EA (2002) Accurately ageing trees and examining their height-growth rates: implications for interpreting forest dynamics. Journal of ecology 90(1):153-166. doi:10.1046/j.0022-0477.2001.00646.x

Hember RA, Kurz WA, Coops NC (2017) Relationships between individual-tree mortality and water-balance variables indicate positive trends in water stressinduced tree mortality across North America. Glob Chang Biol 23(4):1691-1710. doi:10.1111/gcb.13428

Hogg EH, Michaelian M, Hook TI, Undershultz ME (2017) Recent climatic drying leads to age-independent growth reductions of white spruce stands in western Canada. Glob Chang Biol. doi:10.1111/gcb.13795

Huang S, Meng SX, Yang Y (2009) A growth and yield projection system (GYPSY) for natural and post-harvest stands in Alberta. Forestry Division, Albeta Sustainable Resource Devlopment, Edmonton

Lambert MC, Ung CH, Raulier F (2005) Canadian national tree aboveground biomass equations. Can J For Res 35(8):1996-2018. doi:10.1139/X05-112

Larsen CPS (1997) Spatial and temporal variations in boreal forest fire frequency in northern Alberta. J Biogeogr 24(5):663-673. doi:10.1111/j.1365-2699.1997. tb00076.x
Luo Y, Chen HYH (2013) Observations from old forests underestimate climate change effects on tree mortality. Nat Commun 4:1655. doi: 10.1038/ ncomms 2681

Ma Z, Peng C, Zhu Q, Chen H, Yu G, Li W, Zhou X, Wang W, Zhang W (2012) Regional drought-induced reduction in the biomass carbon sink of Canada's boreal forests. Proc Natl Acad Sci U S A 109(7):2423-2427. doi:10.1073/pnas.1111576109

McDowell N, Pockman WT, Allen CD, Breshears DD, Cobb N, Kolb T, Plaut J, Sperry J, West A, Williams DG (2008) Mechanisms of plant survival and mortality during drought: why do some plants survive while others succumb to drought? New Phytol 178(4):719-739

Michaelian M, Hogg EH, Hall RJ, Arsenault E (2011) Massive mortality of aspen following severe drought along the southern edge of the Canadian boreal forest. Glob Chang Biol 17(6):2084-2094. doi:10.1111/j.1365-2486.2010.02357.x

Oliver CD, Larson BC (1990) Forest stand dynamics / by Chadwick Dearing Oliver and Bruce C. Larson Biological resource management series New York : McGraw-Hill Pub Co

Peng $\mathrm{CH}$, Ma ZH, Lei XD, Zhu Q, Chen H, Wang WF, Liu SR, Li WZ, Fang XQ, Zhou XL (2011) A drought-induced pervasive increase in tree mortality across Canada's boreal forests. Nat Clim Chang 1(9):467-471. doi:10.1038/Nclimate1293

R Core Development Team (2017) R: a language and environment for statistical computing. R Foundation for Statistical Computing, Vienna

Réginère J, Saint-Amant R, Béchard A (2014) BioSIM 10 user's manual. Information report LAU-X-137E Natural Resources Canada, Sainte-Foy, QC

Searle EB, Chen HYH (2017a) Persistent and pervasive compositional shifts of western boreal forest plots in Canada. Glob Chang Biol 23(2):857-866. doi: 10.1111/gcb.13420

Searle EB, Chen HYH (2017b) Tree size thresholds produce biased estimates of forest biomass dynamics. Forest Ecol Manag 400:468-474. doi:10.1016/j. foreco.2017.06.042

Ung CH, Bernier P, Guo XJ (2008) Canadian national biomass equations: new parameter estimates that include British Columbia data. Can J For Res 38(5): 1123-1132. doi:10.1139/X07-224

van Mantgem PJ, Stephenson NL, Byrne JC, Daniels LD, Franklin JF, Fule PZ, Harmon ME, Larson AJ, Smith JM, Taylor AH, Veblen TT (2009) Widespread increase of tree mortality rates in the western United States. Science 323(5913):521-524. doi:10.1126/science. 1165000

Vicente-Serrano SM, Begueria S, Lopez-Moreno JI (2010) A multiscalar drought index sensitive to global warming: the standardized precipitation evapotranspiration index. J Clim 23(7):1696-1718. doi:10.1175/2009jcli2909.1

Weir JMH, Johnson EA, Miyanishi K (2000) Fire frequency and the spatial age mosaic of the mixed-wood boreal forest in western Canada. Ecol Appl 10(4): 1162-1177. doi:10.2307/2641024

\section{Submit your manuscript to a SpringerOpen ${ }^{\odot}$ journal and benefit from:}

- Convenient online submission

- Rigorous peer review

- Open access: articles freely available online

- High visibility within the field

- Retaining the copyright to your article

Submit your next manuscript at $>$ springeropen.com 